\title{
Antimicrobial action of the hydroethanolic extract of Spondias mombin L. against oral bacteria of the genus Streptococcus
}

\author{
Ação antimicrobiana do extrato hidroetanólico de Spondias mombin L. frente a bactérias bucais do \\ gênero Streptococcus
}

Acción antimicrobiana del extracto hidroetanólico de Spondias mombin L. contra bacterias orales del género Streptococcus

Received: 27/12/2020 | Reviewed: 28/12/2020 | Accept: 01/16/2021 | Published: 01/19/2021

Thais Oliveira Cordeiro

ORCID: https://orcid.org/ 0000-0003-0078-715X Universidade Federal do Rio Grande do Norte, Brasil E-mail: thaisocodontologia@gmail.com

Angélica Kercya Pereira de Mendonça

ORCID: https://orcid.org/0000-0002-9769-9633 Universidade Federal do Rio Grande do Norte, Brasil E-mail: angélica_kercya@hotmail.com

Mayra Sousa Gomes

ORCID: https://orcid.org/0000-0001-7915-1618 Universidade Federal do Rio Grande do Norte, Brasil E-mail: mayragomes89@gmail.com

Emanuelle Louyde Ferreira de Lima

ORCID: https://orcid.org/0000-0003-2341-7565 Universidade Federal do Rio Grande do Norte, Brasil E-mail: emanuellelouyde@hotmail.com Maria Regina Macedo Costa

ORCID: https://orcid.org/0000-0002-6362-502X Universidade Federal do Rio Grande do Norte, Brasil E-mail: mariaregina@yahoo.com.br

Kenio Costa de Lima

ORCID: https://orcid.org/0000-0002-5668-4398 Universidade Federal do Rio Grande do Norte, Brasil E-mail: linke@uol.com.br

Ruthineia Diógenes Alves Uchôa Lins

ORCID: https://orcid.org/ 0000-0002-0047-5976 Universidade Federal do Rio Grande do Norte, Brasil E-mail: aruthineia@gmail.com

\begin{abstract}
Objective: The purpose of the present study was to compare the in vitro antimicrobial activity of the hydroethanolic extract of Spondias mombin leaf (S. mombin L.) with $0.12 \%$ chlorhexidine digluconate solution on Streptococcus bacterias: S. mutans, S. mitis, S. oralis, S. sanguinis and S. salivarius. Methodology: The Minimum Inhibitory Concentration (MIC), Minimum Inhibitory Concentration of Adherence (MICA) and Bactericidal Kinetics (BK) tests were performed. Results: In regards to the Streptococcus mutans, the control group $(0.12 \%$ chlorhexidine digluconate solution) was statistically superior $(\mathrm{p}<0.05)$ to the extract group up to the concentration of $31.25 \mathrm{mg} / \mathrm{ml}$, with no statistical difference in the other concentrations. For the Streptococcus oralis, the extract group was statistically superior $(\mathrm{p}<0.05)$ to the control group in its crude form $(500 \mathrm{mg} / \mathrm{ml})$ and the control group had statistical significance $(\mathrm{p}<0.05)$ over the extract group at the following concentrations: $62.5 \mathrm{mg} / \mathrm{ml}, 31.25 \mathrm{mg} / \mathrm{ml}, 1.95 \mathrm{mg} / \mathrm{ml}$ and $0.97 \mathrm{mg} / \mathrm{ml}$. For the Streptococcus sanguinis, the extract group was statistically superior $(\mathrm{p}<0.05)$ to the control group in the first two concentrations of $500 \mathrm{mg} / \mathrm{ml}$ and $250 \mathrm{mg} / \mathrm{ml}$, whereas the control group had statistical significance $(\mathrm{p}<0.05)$ on the extract in the last two concentrations: $1.95 \mathrm{mg} / \mathrm{ml}$ and $0.97 \mathrm{mg} / \mathrm{ml}$. The control group was statistically superior (p $<0.05)$ to the extract group in all concentrations for the Streptococcus mitis, except for the concentration of $31.25 \mathrm{mg} /$ $\mathrm{ml}$. For the Streptococcus salivarius, the extract was statistically superior $(\mathrm{p}<0.05)$ to the control group in most concentrations tested, with the exception of $15.65 \mathrm{mg} / \mathrm{ml}$ and $1.95 \mathrm{mg} / \mathrm{ml}$, which did not show statistically significant differences between the groups. Conclusion: the hydroethanolic extract of Spondias mombin L., in distinct concentrations, presents similar antimicrobial activity to $0.12 \%$ chlorhexidine digluconate against the genus Streptococcus oral bacteria.
\end{abstract}

Keywords: Streptococcus; Phytotherapy; Chlorhexidine; Bactericidal agent. 


\begin{abstract}
Resumo
Objetivo: O objetivo do presente estudo foi avaliar in vitro a atividade antimicrobiana do extrato hidroetanólico da folha de Spondias mombin (S. mombin L.) sobre bactérias do gênero Streptococcus: S. mutans, S. mitis, S. oralis, S. sanguinis e S. salivarius, comparando-a à atividade antimicrobiana da solução de digluconato de clorexidina $0,12 \%$ sobre essas mesmas bactérias. Metodologia: Foram realizados os testes in vitro de Determinação da Concentração Inibitória Mínima, Determinação da Concentração Inibitória Mínima de Aderência e Análise da Cinética Bactericida. Resultados: Para o Streptococcus mutans, o grupo controle foi estatisticamente superior $(\mathrm{p}<0,05)$ ao extrato até a concentração $31,25 \mathrm{mg} / \mathrm{ml}$, não ocorrendo diferença estatística nas demais concentrações. Para o Streptococcus oralis, o extrato foi estatisticamente superior $(\mathrm{p}<0,05)$ ao grupo controle em sua forma bruta $(500 \mathrm{mg} / \mathrm{ml})$, o grupo controle teve significância estatística $(\mathrm{p}<0,05)$ sobre o extrato apenas nas concentrações $62,5 \mathrm{mg} / \mathrm{ml}, 31,25 \mathrm{mg} / \mathrm{ml}, 1,95 \mathrm{mg} / \mathrm{ml} \mathrm{e} 0,97 \mathrm{mg} / \mathrm{ml}$. Para o Streptococcus sanguinis, foi constatado que o extrato foi estatisticamente superior $(\mathrm{p}<0,05)$ ao grupo controle nas duas primeiras concentrações $500 \mathrm{mg} / \mathrm{ml}$ e $250 \mathrm{mg} / \mathrm{ml}$, ao passo que o grupo controle teve significância estatística $(\mathrm{p}<0,05)$ sobre o extrato apenas nas duas últimas concentrações: $1,95 \mathrm{mg} / \mathrm{ml}$ e $0,97 \mathrm{mg} / \mathrm{ml}$. O grupo controle foi estatisticamente superior $(\mathrm{p}<0,05)$ ao extrato em todas as concentrações no Streptococcus mitis, exceto para a concentração $31,25 \mathrm{mg} / \mathrm{ml}$. Para a Streptococcus salivarius, o extrato foi estatisticamente superior $(p<0,05)$ ao grupo controle na maioria das concentrações testadas, com exceção apenas para $15,65 \mathrm{mg} / \mathrm{ml}$ e $1,95 \mathrm{mg} / \mathrm{ml}$, que não foram observados diferenças estatisticamente significativas entre o extrato e o grupo controle. Conclusão: o extrato hidroetanólico de Spondias mombin L., em diferentes concentrações, apresenta atividade antimicrobiana semelhante ao digluconato de clorexidina a $0,12 \%$ frente a bactérias bucais do gênero Streptococcus.
\end{abstract}

Palavras-chave: Streptococcus; Fitoterapia; Clorexidina; Agente bactericida.

\title{
Resumen
}

Objetivo: El objetivo de este estudio fue evaluar in vitro la actividad antimicrobiana del extracto hidroetanólico de la hoja de Spondias mombin (S. mombin L.) sobre bacterias del género Streptococcus: S. mutans, S. mitis, S. oralis, S. sanguinis y S. salivarius, comparándola con la actividad antimicrobiana de la solución de digluconato de clorhexidina al 0,12\% sobre estas mismas bacterias. Metodología: Se realizaron pruebas in vitro de Determinación de Concentración Mínima Inhibidora, Determinación de Concentración Mínima Inhibidora de Adhesión y Análisis de Cinética Bactericida. Resultados: Para Streptococcus mutans, el grupo control fue estadísticamente superior $(\mathrm{p}<0.05)$ al extracto hasta la concentración de $31.25 \mathrm{mg} / \mathrm{ml}$, sin diferencia estadística en las otras concentraciones. Para Streptococcus oralis, el extracto fue estadísticamente superior ( $\mathrm{p}<0.05)$ al grupo de control en su forma cruda $(500 \mathrm{mg} / \mathrm{ml})$, el grupo de control tuvo significación estadística $(\mathrm{p}<0.05)$ sobre el extracto solo en concentraciones $62,5 \mathrm{mg} / \mathrm{ml}, 31,25 \mathrm{mg} /$ $\mathrm{ml}, 1,95 \mathrm{mg} / \mathrm{ml}$ y 0,97 mg / ml. Para Streptococcus sanguinis, se encontró que el extracto fue estadísticamente superior ( $\mathrm{p}<0.05$ ) al grupo control en las dos primeras concentraciones $500 \mathrm{mg} / \mathrm{ml}$ y $250 \mathrm{mg} / \mathrm{ml}$, mientras que el grupo control tuvo significación estadística ( $\mathrm{p}<0.05$ ) en el extracto solo en las dos últimas concentraciones: $1,95 \mathrm{mg} / \mathrm{ml}$ y $0,97 \mathrm{mg}$ / ml. El grupo de control fue estadísticamente superior $(\mathrm{p}<0,05)$ al extracto en todas las concentraciones en Streptococcus mitis, excepto para la concentración de $31,25 \mathrm{mg} / \mathrm{ml}$. Para Streptococcus salivarius, el extracto fue estadísticamente superior $(\mathrm{p}<0,05)$ al grupo de control en la mayoría de las concentraciones analizadas, con la excepción de solo $15,65 \mathrm{mg} / \mathrm{ml}$ y $1,95 \mathrm{mg} / \mathrm{ml}$, que no mostraron diferencias estadísticamente significativas entre el extracto y el grupo de control. Conclusión: el extracto hidroetanólico de Spondias mombin L., en diferentes concentraciones, presenta actividad antimicrobiana similar al digluconato de clorhexidina al $0.12 \%$ contra bacterias orales del género Streptococcus.

Palabras clave: Streptococcus; Fitoterapia; Clorhexidina; Agente bactericida.

\section{Introduction}

It is widely recognized that most aerobe and facultative anaerobe microorganisms found in nature, rarely exist in a planktonic state, and are usually organized in biofilms. Biofilms represent a complex microbial community, consisting of a wide variety of microorganisms, with different ecological requirements and potential pathogens (Stewart et al., 2001).

The biofilm is formed through a multistage process that begins with microbial adhesion with subsequent production and accumulation of an extracellular matrix composed by one or more polymeric substances, such as proteins, polysaccharides, humic substances, extracellular DNA and other cellular communication molecules (Flemming, \& Wingender, 2010).

The dental biofilm formation is a continuous and structurally complex process, which involves several distinct stages of maturity: initial bacterial adhesion to the acquired enamel pellicle or other exposed surfaces; growth of attached bacteria; aggregation, co-aggregation and microbial succession; and formation of mature biofilm (Stewart et al., 2001).

In order to reduce the microbial pathogenicity in the oral tissues and prevent the development and / or progression of caries and periodontal diseases, regular and appropriate oral hygiene methods that disrupt and remove the biofilm are required 
(Pan, et al.; March, 2010). The most accepted and recommended method for the biofilm removal is the mechanical control (Van der Weijden \& Hioe ,2005). Nevertheless, whenever limitations are found, such as individual's lack of manual skills or motivation, chemical agents have been proposed to reduce bacterial adhesion to surfaces, inhibit the growth and proliferation of microorganisms in the oral environment, modify the biochemistry of these microorganisms and change the biofilm ecology to a less pathogenic microbiome, at levels compatible with oral health (March, 2010; Torres et al., 2000; Gunsolley, 2010).

Despite the existence of several antimicrobial chemical agents in toothpastes and mouthwashes, an ideal agent capable of reducing the oral biofilm pathogenicity, promoting clinical benefits, without altering the natural oral microbiota or causing tissue damage has not yet been developed (Bergenholtz, 2016; Pourhajibagher \& Bahador, 2015). Currently, the 0.12\% chlorhexidine digluconate have proven to have a broad spectrum of activity, low toxicity and high substantivity, being the gold standard for chemical biofilm control (Swango, 2012). However, its prolonged use is not recommended as it alters the natural microbiota and produces undesirable side effects such as taste alterations, mucosa desquamation and teeth and restorations staining (Matos, 2015; Hajifattahi, 2016).

Nonetheless, there are many medicinal plants with antimicrobial compounds (Sadaka, 2014) and the biomolecules isolated from these plants have been suggested as alternative antimicrobial agents to synthetic chemical agents, with little or no side effects (Palombo, 2011). Hence, in vitro studies on the antimicrobial action of plant extracts obtained from stems, leaves and / or roots has been developed aiming to discover new preventive and therapeutic options for oral infections and in the daily outpatient practice (Aleluia, 2015; Chiniforush, 2016). Among these extracts, we highlight the leaf extract of Spondias mombin, a popular plant in Latin America, which its antimicrobial action was previously confirmed through phytochemical studies (Asuquo, 2012).

Given the above, the objective of the present study was to evaluate the antimicrobial activity in vitro of the hydroethanolic extract of the leaf of Spondias mombin (S. mombin L.) on bacteria of the genus Streptococcus: S. mutans, S. mitis, S. oralis, S. sanguinis and S. salivarius, comparing it to the antimicrobial activity of the $0.12 \%$ chlorhexidine digluconate solution on the same groups of bacteria.

\section{Materials and Methods}

\section{Obtaining plant material and preparing the hydroethanolic extract}

This study is characterized as an "in vitro" laboratory test (Pereira, A.S. et al. 2018) S. mombin leaves were collected in the city of Natal, Rio Grande do Norte, Brazil; the voucher specimen was deposited in the herbarium of the Federal University of Rio Grande do Norte (UFRN), with the number of exsiccata 12252; and the crude hydroethanolic extract was prepared at the Pharmacognosy Laboratory of the Pharmacy Department of the Federal University of Rio Grande do Norte (UFRN).

After collection, the leaves of Spondias mombin were dried in a forced air ventilation oven, at an average temperature

of $40^{\circ} \mathrm{C}$. The dried leaves were grounded into powder with a mechanical grinder and subsequently macerated with $800 \mathrm{ml}$ of 95\% ethanol for 72 hours to obtain the hydroethanolic extract. The hydroethanolic extract was concentrated in a rotary evaporator, under reduced pressure, at a temperature that did not exceed $45^{\circ} \mathrm{C}$, and lyophilized. The extract was also submitted to phytochemical screening and analysis by CCD, previously described by (Cabral et al., 2016).

\section{Cultivation of microorganisms}

The following microorganisms were tested: Streptococcus mitis (ATCC 903), Streptococcus mutans (ATCC 10449), Streptococcus sanguinis (ATCC 7863), Streptococcus oralis (ATCC 10557) and Streptococcus salivarius (ATCC 7073). These strains were initially obtained in nutrient broth (BHI - Brain Heart Infusion - DIFCO®, Michigan, United States) and, with the aid of a disposable loop, the sample were streaked in three directions (horizontal, vertical and diagonal) in Petri dishes containing 
Blood Agar (Columbia Blood Agar Base - DIFCO®, Michigan, United States) that stayed in a greenhouse for 24 hours at $37^{\circ}$ C. Then, the bacterial cultures were removed from these plates, maintained in nutrient broth (BHI - Brain Heart Infusion - DIFCO ${ }^{\circ}$ Michigan, United States) and incubated for 18 to 20 hours, at $37^{\circ} \mathrm{C}$. The Minimum Inhibitory Concentration (MIC), Minimum Inhibitory Concentration of Adherence (MICA) and Bactericidal Kinetics (BK) tests were performed.

\section{Determination of Minimum Inhibitory Concentration (MIC)}

The MIC of the extract was evaluated in vitro, according to the method of Bauer et al. (1966) (Bauer et al., 1966). The nutrient broth with each bacterial culture was spread on Petri dishes containing Mueller-Hinton agar, where five equidistant holes were drilled, measuring approximately $6 \mathrm{~mm}$ in diameter in each dish. $70 \mu \mathrm{L}$ of each test substance (crude extract diluted in distilled water to 1: 512) were introduced into these holes and the plates were incubated at $37^{\circ} \mathrm{C}$ for 24 hours under microaerophilic conditions. Each trial was performed in triplicate. The same procedure was performed with the control substance - $0.12 \%$ chlorhexidine digluconate solution (Periogard®, Colgate-Palmolive Company, New York, USA). At the end of the incubation period, the diameters of the inhibition halos were measured (in mm) with a caliper (Digimess®, São Paulo, Brazil) and the lower concentration of the extract able to develop inhibition growth was considered as the MIC.

The following interpretation parameters were used, according to the diameter of the inhibition zone, as suggested by Smânia et al. (1999) [22]: inactive (without inhibition zone or inhibition zone less than $9 \mathrm{~mm}$ ); partially active (inhibition zone between 9 and $12 \mathrm{~mm}$ ); active: inhibition zone between 13 and $18 \mathrm{~mm}$ ) and very active (inhibition zone more than $18 \mathrm{~mm}$ ). The results were transferred to a database and analyzed using the Mann-Whitney U test, with a significance level of 5\%.

\section{Determination of Minimum Inhibitory Concentration of Adherence (MICA)}

The CIMA of the extract was determined in the presence of 5\% sucrose, as described by Gerbara, Zardetto and Mayer (1996) (Gebara et al., 1996), using concentrations corresponding to the crude extract and diluted to 1:512. The bacterial strains were sub-cultivated in Mueller-Hinton broth (DIFCO) at $37^{\circ} \mathrm{C}$. Subsequently, $0.9 \mathrm{~mL}$ of the subculture was distributed in hemolysis tubes where $0.1 \mathrm{ml}$ of the solutions corresponding to the extract (crude and diluted) was further added. The incubation was performed for 24 hours in microaerophilia, with the tubes inclined at a $30^{\circ}$ angle. The reading was performed 24 hours after the test by visual inspection, after agitation, of the presence or absence of bacteria adhered to the tube walls. Each trial was carried out in triplicate. The same procedure was performed with the control substance - the $0.12 \%$ chlorhexidine digluconate solution (Periogard®, Colgate-Palmolive Company, New York, USA). MICA was defined as the lowest concentration of the extract in the presence of sucrose to prevent bacterial adhesion to the glass tube.

\section{Determination of Bactericidal Kinetics (BK)}

The bactericidal activity of the extract of S. mombin L. was evaluated by the method of Peyret et al. (1990) (Peyret et al., 1990). The microbial samples were inoculated in nutrient broth (BHI-DIFCO, Michigan, United States), incubated at $37^{\circ} \mathrm{C}$ for 18 to 20 hours and subcultured in Mueller Hinton Broth (DIFCO, Michigan, United States) for 1 hour, obtaining an inoculum of $106 \mathrm{CFU} / \mathrm{mL} .1 \mathrm{~mL}$ of the extracts (crude and MIC) was added to the $9 \mathrm{~mL}$ of bacterial culture, and $1 \mathrm{~mL}$ of $0.12 \%$ chlorhexidine digluconate was added to the control tube. The tubes were kept in the greenhouse at $37^{\circ} \mathrm{C}$ for 24 hours, and aliquots were removed after 2, 4, 6 and 24 hours of incubation and placed in plates with Mueller Hinton Agar (DIFCO, Michigan, United States). Each trial was carried out in duplicate. The reading was performed after incubation for 24 hours at $37^{\circ} \mathrm{C}$ by the standard method of counting colony-forming units (CFU), observing the bactericidal potential of the extracts and $0.12 \%$ chlorhexidine digluconate at the determined time intervals. 


\section{Statistical analysis}

The results regarding the Minimum Inhibitory Concentration (MIC) were collected, organized and presented in tables, with the averages of the halos indicating the inhibition of bacterial growth. Subsequently, these values were transferred to a database and the statistical parameters that included the values of the respective means and standard deviations were calculated. The confidence level used to obtain the intervals was $95 \%$. At the $5 \%$ level of significance, Student's $t$ test was used to compare the halo inhibition obtained from the Minimum Inhibitory Concentrations (MIC) of the extracts with each other and in relation to the $0.12 \%$ chlorhexidine digluconate, regarding the two microorganisms investigated. The data on the chemical characterization of the extract, the Minimum Inhibitory Concentration of Adherence (MICA) and Bactericidal Kinetics (BK) were organized and analyzed in a descriptive manner.

\section{Results}

\section{Analysis of Minimum Inhibitory Concentration (MIC)}

The hydroethanolic extract of S. mombin L. (HE) revealed activity on the tested microorganisms, with halo inhibition varying up to $27 \mathrm{~mm}$ (Table 1).

For the Streptococcus mutans, the control group was statistically superior $(\mathrm{p}<0.05)$ to the extract group up to the concentration of $31.25 \mathrm{mg} / \mathrm{ml}$ (1:16 dilution), with no statistical difference between the two substances for the other concentrations. For the Streptococcus oralis, the extract group was statistically superior to the control group in its crude form of $500 \mathrm{mg} / \mathrm{ml}$ (dilution 1: 1), while the control group was statistically superior in the concentrations $62.5 \mathrm{mg} / \mathrm{ml}$ (dilution 1: 8), $31.25 \mathrm{mg} / \mathrm{ml}$ (dilution 1:16), 1.95mg / $\mathrm{ml}$ (dilution 1: 256) and $0.97 \mathrm{mg} / \mathrm{ml}$ (dilution 1: 512). For the Streptococcus sanguinis, the extract group was statistically superior in the first two concentrations $500 \mathrm{mg} / \mathrm{ml}$ (dilution 1:1) and 250mg / $\mathrm{ml}$ (dilution 1: 2), whereas the control group was statistically superior in the last two concentrations: $1.95 \mathrm{mg} / \mathrm{ml}$ (dilution 1: 256) and $0.97 \mathrm{mg}$ $/ \mathrm{ml}$ (dilution 1: 512). The control group was statistically superior $(\mathrm{p}<0.05)$ to the extract group at all concentrations tested on the microorganism Streptococcus mitis, except for the concentration of $31.25 \mathrm{mg} / \mathrm{ml}$ (1:16 dilution) in which there was no statistical difference between the substances. For the Streptococcus salivarius, the extract group was statistically superior to the control group in most concentrations tested, except $15.65 \mathrm{mg} / \mathrm{ml}$ (1:32 dilution) and 1.95mg / $\mathrm{ml}$ (dilution 1: 256), in which no statistically significant differences were observed.

\section{Analysis of Minimum Inhibitory Concentration of Adherence (MICA)}

The hydroethanolic extract of S. mombin L. showed an anti-adherence effect on all tested bacteria until the last diluted concentration $(0.97 \mathrm{mg} / \mathrm{ml})$, except for the Streptococcus mitis, in which the extract inhibited adherence up to the concentration of $31,25 \mathrm{mg} / \mathrm{ml}$. This anti-adherence effect was superior to that found by $0.12 \%$ chlorhexidine digluconate for the Streptococcus mutans, Streptococcus oralis, Streptococcus sanguinis and Streptococcus salivarius. For the Streptococcus mitis, $0.12 \%$ chlorhexidine digluconate exhibited the greatest anti-adherence activity.

\section{Analysis of Bactericidal Kinetics (BK)}

The hydroethanolic extract of S. mombin L., in its crude form, exhibited bactericidal effect for 6 hours for the Streptococcus oralis, Streptococcus mutans and Streptococcus salivarius. For the Streptococcus mitis, there was no microbial growth in any of the time intervals, while for Streptococcus sanguinis, the crude extract showed bactericidal effect in the first 2 hours of contact.

In the tests performed with the Minimum Inhibitory Concentration (MIC) of the extract, a bactericidal effect was observed on the Streptococcus sanguinis in the first 2 hours of contact with the bacteria; for the Streptococcus salivarius, a 
bactericidal effect was observed in the first 4 hours of contact; and the greater effect was observed for the Streptococcus oralis, in which the extract allowed 6 hours of absence of microbial growth. No bacterial growth was observed in any of the time intervals for the Streptococcus mutans and Streptococcus mitis. The control group showed a bactericidal effect for all investigated microorganisms, both in their crude concentration and in their MIC, in all investigated time intervals.

\section{Discussion}

Synthetic antimicrobial agents are widely used in oral health care, however, its excessive use or its use without an adequate indication, can eventually increase bacterial resistance and cause side effects. In this context, the antimicrobial action of a great variety of Brazilian plant extracts has been extensively studied. Thus, studies regarding the ethnopharmacological characterization and the phytochemical of the extracts are necessary to safely denoted them as an antimicrobial agent (Medeiros et al., 2013).

The present study performed the phytochemical screening of a plant extract commonly found in Latin American countries, S. mombim L., and compared its antimicrobial activity against five microorganisms of the Streptococcus group present in the oral cavity (S. mutans, S. oralis, S. sanguinis, S. mitis and S. salivarius) with the antimicrobial activity of $0.12 \%$ chlorhexidine digluconate solution, considered the gold standard in Dentistry.

The streptococcus microorganisms are important components of the dental biofilm since most of these bacteria contribute to its initial formation and form part of the resident microbiota of the oral cavity (Zheng; Hua; Cheung, 2011). In fact, studies have shown a correlation between the presence of Streptococcus mutans with carious lesions incidence, which is explained by their ability to ferment carbohydrates from the individual's diet and develop a cariogenic biofilm on dental surfaces (Bueno-Silva, et al., 2013).

In the study by Cabral et al (2016), phytochemical prospecting and Thin Layer Chromatography analysis revealed that the Spondias mombin L. extract has, in its constitution, phenolic compounds, flavonoids, tannins and saponins, and those constituents exhibited antimicrobial activity, which corroborates what was found in the study by Medeiros et al. (2013). Therefore, it may be suggested that the effectiveness of the S. mombin L. extract as an antimicrobial agent, could be related to the presence of these metabolites.

The phenolic compounds of the metabolites present in the extract of Spondias mombin L., also have antibiotic, antitumor, antioxidant, antiviral and allergenic actions, while flavonoids stand out for their antioxidant action (Thadhani et al., 2012) and tannins, for its antimicrobial activity (Gülçin et al., 2010). Saponins, on the other hand, also found in the plant extract of Spondias mombin L. have anti-inflammatory action (Yao et al., 2014) could justify further investigation on this matter.

In the present study, the inhibitory action of bacterial growth of S. mombin L. extract and $0.12 \%$ chlorhexidine digluconate on Streptococcus bacteria was evaluated by means of MIC, which is considered the most appropriate method for this purpose ( Natarajan et al., 2005). This test allows the confirmation of the microorganism's resistance to an antimicrobial agent, as well as it monitors the activity of new antimicrobial agents, in their initial phases. Through this technique, recent research has shown that, to potentiate and amplify the antimicrobial effect, the Spondias extract can also be used synergistically with other antibiotics already established in medicine (Alencar,2015).

The present research revealed that the hydroethanolic extract of S. mombin L. showed inhibition of bacterial growth activity on the tested microorganisms, with inhibition halo between $9 \mathrm{~mm}$ and $27 \mathrm{~mm}$. The literature shows that an inhibition halo starting at $9 \mathrm{~mm}$ already denotes some inhibitory action on microbial growth, being the extract partially effective (Smania et al., 1999). In our results, the bacterium Streptococcus salivarius was the microorganism most sensitive to the extract, when compared to the control group, contrary to the results found in the research by Shakerian et al. (Shakerian et al., 2018) who found that the bacterium Streptococcus salivarius was more sensitive to chlorhexidine digluconate than to the Spondias mombin L. extract 
(Shakerian et al., 2018).

The extract of Spondias mombin L., in its crude concentration, was more active than the control group for the Streptococcus oralis and sanguinis, which can be justified by the greater availability of the plant found in the crude form. Our results also considered the control group as the gold standard for Streptococcus mutans and mitis, corroborating with some studies in the literature (Silva et al., 2015; .Jesus et al., 2010) The use of several other extracts as antimicrobial agents is widely investigated for the bacterium Streptococcus mutans, strongly associated with the etiology of dental caries.

This research also verified the anti-adherent effect of Spondias mombin L. extract since the adhesion of bacteria to the acquired enamel film defines an important mechanisms involved in the biofilm formation (Jongsma et al., 2015). Therefore, it is always advisable to investigate the anti-adherent potential of a plant extract due to its implications in preventing the formation of dental biofilm and reduce the occurrence of biofilm-dependent oral diseases, such as dental caries and periodontal disease (Jongsma et al., 2015).

When analyzing the Minimum Inhibitory Concentration of Adherence (MICA) of S. mombin L. extract against microorganisms of the Streptococcus group, it was observed that the plant extract was superior to $0.12 \%$ chlorhexidine digluconate for the microorganisms Streptococcus mutans, Streptococcus oralis, Streptococcus sanguinis and Streptococcus salivarius, with the only exception being the Streptococcus mitis. This bacterial resistance to the anti-adherent effect may be explained by the acidogenic and aciduric properties of the Strepctococcus mitis, and their ability to produce extracellular polysaccharides, which can make the environment cariogenic (Schlafer et al., 2011).

In general, the results obtained in this research regarding the anti-adherent effect of the plant extract of Spondias mombin L. on bacteria of the genus Streptococcus suggest that this extract can be used in the chemical control of dental biofilm. However, studies with microorganisms organized in biofilm are necessary to validate its anti-biofilm effect.

As for the bactericidal effect, the results of this research revealed that the plant extract, in its crude and diluted concentrations, exhibited bactericidal action in the first two hours of initial contact with the studied microorganisms. This reveals positive implications of using this extract in clinical situations, as a mouthwash. Additionally, studies involving cell culture have shown that the extract, even in its crude concentration, did not have a cytotoxic effect on the oral mucosa (Cabral et al.,2016). However, a more detailed investigation about its relationship with restorative materials and the dental surface is still necessary.

Nonetheless, it is important to note that the control group showed a better result, with no microbial growth in any proposed time interval. The $0.12 \%$ chlorhexidine digluconate, showed a continuous action, for about 12 hours after its use, corroborating other reports found in the literature (Quintas et al., 2015). The chlorhexidine has not only an immediate bactericidal action, but also has substantivity, i.e., an intrinsic ability to be retained by oral surfaces, and gradually released into oral fluids over many hours (Marsh, 2010). Controlled and randomized clinical trials are necessary to better investigate the substantivity of the Spondias mombin L extract.

The present research showed the potential of using the hydroethanolic extract of Spondias mombin L. when compared to chlorhexidine, highlighting its effective antimicrobial agents on microorganisms of the dental biofilm. Nevertheless, the study has limitations such as the exclusive use of commercialized strains (ATCC) and the investigation of these microorganisms only in the planktonic form. It is recommended, therefore, further studies to assess microorganisms in mixed cultures and organized in biofilm.

\section{Conclusions}

The hydroethanolic extract of Spondias mombin L., in distinct concentrations, has antimicrobial activity similar to $0.12 \%$ chlorhexidine digluconate against the genus Streptococcus oral bacteria.

The results of this work demonstrate the effectiveness of the herbal medicine Spondia mombin L. in oral bacteria, we 
suggest that controlled randomized clinical studies be carried out in order to demonstrate the results in the oral cavity, due to the importance of having an oral rinse that does not harm society.

\section{Declarations of interest}

None.

\section{Acknowledgment}

We thank the University Federal do Rio Grande do Norte, for making laboratories available e a Coordination for the Improvement of Higher Education Personnel (CAPES) to be financed this research.

\section{References}

Aleluia, C. M., et al. (2015). Medicines In Dentist Herbal. Rev. Odontol. Univ. São Paulo, 27 (2), 126-134.

Alencar, L. C. B., et al. (2015). Modulatory effect of the extract of medicinal plants of the genus Spondias on the resistance of Staphylococcus aureus strains to Erythromycin. Journal of Basic and Applied Pharmaceutical Sciences, 36(1).

Asuquo, O. R., et al. (2012). Hitomorphological study of the anti-fertility effect of Spondias mombin L. in adult male rats. Journal of pharmacyand biological sciences, 3, 29-34.

Bauer, A. W., Kirby, W. M., Sherris, J. C., \& Turck, M. (1966). Antibiotic susceptibility testing by a standardized single disk method. American journal of clinical pathology, 45(4), 493.

Bergenholtz, G. (2016). Assessment of treatment failure in endodontic therapy, J. Oral.Rehabil., 753-758.

Bueno-Silva, B. et al. (2013). Effect of neovestitol - vestitol containing Brazilian red propolis on accumulation of biofilm in vitro and development of dental caries in vivo. Biofouling, 29, 1233-1242.

Cabral, B., Siqueira, E., Bitencourt, M. A., Lima, M. C., Lima, A. K., Ortmann, C. F., \& Reginatto, F. H. (2016). Phytochemical study and anti-inflammatory and antioxidant potential of Spondias mombin leaves. Revista Brasileira de Farmacognosia, 26 (3), 304-311.

Chiniforush, N., Pourhajibagher, M., Shahabi S., Kosarieh E. \& Bahador, A. (2016). Can Antimicrobial Photodynamic Therapy (aPDT) Enhance the Endodontic Treatment? J. Lasers. Med. Sci., 76-85.

Flemming, Hans-Curt \& Wingender, Jost (2010). The biofilm matrix. Nature reviews microbiology, 8(9), 623-633.

Gebara, E. C. E., Zardetto, C. G. D. C., \& Mayer, M. P. A. (1996).In vitro study of the antimicrobial action of natural substances on S. mutans and S.sobrinus. Rev Odontol Univ. 10 (4), 251- 256.

Gülçin, İ., Huyut, Z., Elmastaş, M., \& Aboul-Enein, H. Y. (2010). Radical scavenging and antioxidant activity of tannic acid. Arabian Journal of Chemistry, 3(1), 43-53.

Gunsolley, J. C. (2010). Clinical efficacy of antimicrobial mouthrinses. Journal Dent., 38, S6-S10.

Hajifattahi, F., Maravej, S. E., Taheri, M., Arash, M., \& Kamalinejad, M. (2016). Antibacterial effect of hydroalcoholic extract of Punica granatum Linn. Petal on common oral microorganisms. Inter. J. Biomat, 1-6.

Jesus, R. P. F. S., et al. (2010). Antibacterial and nonstick action of pithecellobium Cochliocarpum (gomez) macbr on oral microorganisms. Odontol. Clín.-Cient. 9 (4), 331-335.

Jongsma, M. A., Van de Lagemaat, M., Busscher, H. J., Geertsema-Doornbusch, G. I., \& Atema-Smit, J., Van Der Mei, H. C., \& Ren, Y.(2015). Synergy of brushing mode and antibacterial use on in vivo biofilm formation. Journal of dentistry, 43(12), 15801586.

Khémiri,I. et al. (2019).The A ntimicrobial and Wound Healing Potential of Opuntia ficus indica L. inermis Extracted Oil from 
Tunisia. Evid Based Complement Alternat Med. 10.1155/2019/9148782

Marsh, P. D. (2010). Controlling the oral biofilm with antimicrobials. Journal Dent., 38, S11-S15.

Matos, L. M. R. et al. (2015). Effect of Antiseptic with and without alcohol on the oral microbiota. R. Interd, 8, (4), 174-180.

Medeiros, P. M., Ladio, A. H., Santos, A. M. M., \& de Albuquerque, U. P. (2013). Does the selection of medicinal plants by Brazilian local populations suffer taxonomic influence? Journal of ethnopharmacology, 146(3), 842-852.

Natarajan, D., Britto, S. J., Srinivasan, K., Nagamurugan, N., Mohanasundari, C., \& Perumal, G. (2005). Anti-bacterial activity of Euphorbia fusiformis - A rare medicinal herb. Journal of ethnopharmacology, 102 (1), 123-126.

Palombo E.A. (2011). Traditional Medicinal Plant Extracts and Natural Products with Activity against Oral Bacteria: Potential Application in the Prevention and Treatment of Oral Diseases. Evid Based Complement Alternat Med. doi.org/10.1093/ecam/nep067.

Pan, P. C. et al. (2010). In-vitro evidence for efficacy of antimicrobial mouthrinses. Journal Dent., 38, S16-S20.

Pereira A. S. et al. (2018). Scientific research methodology. Ed. UAB/NTE/UFSM. https://repositorio.ufsm.br/bitstream/ handle/1/15824/Lic_Computacao_Metodologia-Pesquisa-Cientifica.pdf?sequence=1.

Peyret, M., Carret, G., Carre, C., Fardel, G., \& Flandrois, J. P. (1990). Mathematical study of the sensitivity curves of Escherichia coli exposed to polymyxins. Pathol Biol, 38,441-445.

Pourhajibagher, M., \& A. Bahador, A. (2015). Is antimicrobial agent can considered as effective weapons against endodontic infections by Enterococcus faecalis? Der Pharma Chemica, 196-200.

Pyysalo, Mikko J. et al. (2019). Increased brushing frequency is associated with reduced gingival bag bacterial diversity in patients with intracranial aneurysms. Peer Journal, 7,6316.

Quintas, V., Prada-Lopez, I., Donos, N., Suarez-Quintanilla, D., \& Tomas, I. (2015). In situ neutralisation of the antibacterial effect of $0.2 \%$ Chlorhexidine on salivary microbiota: Quantification of substantivity. Archives of oral biology, 60(8), $1109-1116$.

Sadaka F., Nguimjeu C., Vroman I., Tighzert L. \& Couvercelle J. P. (2014). Review on antimicrobial packaging containing essential oils and their active biomolecules. Innov. Food Sci. Emerg. Technol: Brachais $\mathrm{CH}$.

Schlafer, S., Raarup, M. K., Meyer, R. L., Sutherland, D. S., Dige, I., Nyengaard, J. R., et al.(2011). pH Landscapes in a novel five-species model of early dental biofilm. PLoS One, 6 (9).

Shakerian, M., Yaghoti, M. M., \& Doostaki, S. (2018). In Vitro Effect of Hydroalcoholic Extract of Aloe Vera and 0.2\% Chlorhexidine Mouthwash on Streptococcus Sanguinis, Streptococcus Salivarius and Streptococcus Mutans. Journal of Dental School, Shahid Beheshti University of Medical Sciences, 36 (1), 18-22.

Silva, V. A. et al. (2013). Antimicrobial efficacy of the extract of Croton sonderianus Müll. on bacteria that cause dental caries. Revista de Odontologia da UNESP, 40 (2), 69-72.

Smania Jr, A., Monache, F. D., Smania, E. D. F. A., \& Cuneo, R. S. (1999). Antibacterial activity of steroidal compounds isolated from Ganoderma applanatum (Pers.) Pat. (Aphyllophoromycetideae) fruit body. International Journal of medicinal mushrooms, $1(4)$.

Stewart, P. S., Rayner, J., Roe, F., \& Rees W. M, (2001). Biofilm penetration and disinfection efficacy of alkaline hypochlorite and chlorosulfamates. Journal Appl Microbiol; 91:525-32.

Swango, P. A. (2012). Regular use of antimicrobial mouthrinses can effectively augment the benefits of oral prophylaxis and oral hygiene instructions at 6-month recall intervals in reducing the occurrence of dental plaque and gingivitis. Journal Evid Based Dent Pract., 12 (2), 87-89.

Thadhani, V. M., Choudhary, M. I., Khan, S., \& Karunaratne, V. (2012). Antimicrobial and toxicological activities of some depsides and depsidones. Journal of the National Science Foundation of Sri Lanka, 40(1), 43-48.

Torres, C. R. G., Kubo, C. H., Anido, A., \& Rodrigues, J. R. (2000). Antimicrobial agents and your potential of use in odontology. PGR: Pós-Grad Rev Fac Odontol São José dos Campos. 3, 43-52. 
Van der Weijden, G. A., \& Hioe, K. P. K. (2005). A systematic review of the effectiveness of mechanical plaque removal performed in adults with gingivitis using a manual toothbrush. Jornal de Periodontologia clínica, 32, 214-228.

Yao, Y., Yang, X., Shi, Z., \& Ren, G. (2014). Anti-Inflammatory Activity of Saponins from Quinoa (Chenopodium quinoa Willd.) Seeds in Lipopolysaccharide-Stimulated RAW Macrophages Cells. Journal of food science, 79(5).

Zheng, L. W., Hua, H., \& Cheung, L. K. (2011). Traditional Chinese medicine and oral diseases: today and tomorrow. Oral Dis., 17, (1), 7-12. 